\title{
Trade and Agricultural Disease: Import Restrictions in the Wake of the India- Agricultural Products Dispute
}

\author{
KAMAL SAGGI* \\ Vanderbilt University \\ MARK WU** \\ Harvard Law School
}

\begin{abstract}
Trade in agricultural products raises sensitivities, particularly when imports originate from a trading partner experiencing an outbreak of some type of agricultural disease. In this article, we explain why despite the negative externalities associated with diseased imports, an importing country is generally not permitted to ban such imports outright under WTO law. Rather, it is allowed to do so only under specific circumstances. We also highlight how the recent India-Agricultural Products ruling contributes to the jurisprudence of two issues concerning the SPS Agreement: the interpretation of international standards, and the relationship between the risk assessment and scientific evidence requirements.
\end{abstract}

\section{Introduction}

Global exports of agricultural goods exceeded \$1.7 trillion in 2014, with food accounting for over $80 \%$ of the total value (WTO, 2015). Such cross-border movement of food and agricultural goods helps ensure the sustenance and economic well-being of billions around the world. Yet, trade rules for agriculture remain an extremely sensitive issue. This is particularly the case when agricultural imports carry the threat of disease.

Not surprisingly then, under the rules of the World Trade Organization (WTO), member countries are allowed to restrict the importation of agricultural products from diseased regions. However, if governments could do so without limitation then this freedom could quickly devolve into a protectionist excuse that has the potential to seriously thwart trade liberalization in the agricultural sector. The relevant WTO rules therefore must seek to balance two competing objectives - providing sufficient flexibility for sovereign governments to regulate imports from diseased regions while simultaneously culling out protectionist measures for

* Email: k.saggi@vanderbilt.edu

**Email: mwu@law.harvard.edu 
which the threat of diseased imports simply serves as an excuse for keeping imports at bay. Getting this balance right is tricky. In 1994, Uruguay Round negotiators drafted the Agreement on Sanitary and Phytosanitary Measures (SPS Agreement) to spell out in detail the requirements that a WTO member must follow when seeking to ban or restrict imports of agricultural goods.

In the intervening two decades, several high-profile and controversial WTO cases have arisen concerning imports of agricultural goods that might serve as conduits for introducing new diseases to importing nations. ${ }^{1}$ However, until 2012, all of these disputes concerned restrictions enacted by developed countries. The India-Agricultural Products dispute ${ }^{2}$ represented the first time that a developing country's restrictions on agricultural imports from a diseased region were challenged before the WTO.

Developing countries, of course, have several special considerations worth bearing in mind. Because a higher proportion of households rely upon subsistence agriculture, the introduction of a diseased product may prove more devastating than would be the case elsewhere. Furthermore, inspectors in developing countries may have fewer resources and/or less capacity to weed out diseased agricultural imports than their peers in advanced economies.

What is a developing country to do when a communicable disease has broken out in a trading partner's territory but the trading partner insists that its potentially tainted products ought to be allowed in freely? Can, and should, the developing country enact an outright import ban? Or is a more finely calibrated import quota called for? Can such a trade policy be applied to all imports of that good from the trading partner, even if the disease is confined to a particular geographic region? Or is such an act overly cautious and protectionist, especially since many of its trading partners' agricultural products may not be diseased?

These very questions surfaced in the recent India-Agricultural Products dispute. In that case, India sought to prohibit imports of poultry meat, eggs, and other agricultural products from trading partners afflicted with avian influenza (AI) - commonly known as 'bird flu' - in order to protect its domestic poultry stock. The WTO Appellate Body confirmed once more that a WTO Member does not have full regulatory flexibility to enact an outright ban on agricultural imports from a given trading partner afflicted with an agricultural disease. Instead, that measure must be compared against existing international standards, guidelines, and recommendations. Furthermore, a government must offer evidence that the import restriction is necessary and based on scientific principles. The Appellate Body clarified that a WTO Member need not necessarily conduct a risk assessment to

1 Such cases include Australia - Measures Affecting Importation of Salmon(DS18), Japan - Measures Affecting Agricultural Products (DS76), Japan - Measures Affecting the Importation of Apples (DS245), and Australia - Measures Affecting the Importation of Apples from New Zealand (DS367).

2 Appellate Body Report, India - Measures Concerning the Importation of Certain Agricultural Products, WT/DS430/AB/R (4 June 2015) (India-Agricultural Products). 
meet this requirement. However, this does not obviate a WTO member from a separate treaty requirement to perform a risk assessment.

This Article discusses and assesses the legal and economic rationale for the Appellate Body's ruling. We explain why an outright ban on imports will generally prove to be excessive from a social welfare perspective. We develop a simple economic framework that shows how the optimal import policy is linked to the degree of damage caused by tainted imports. The SPS Agreement emphasizes the importance of international standards, risk assessment, and scientific evidence in determining the optimal policy response of an importing country when imports carry the threat of disease. We discuss how the Appellate Body ruling contributes to our jurisprudential understanding of these elements. Finally, we draw attention to the controversy concerning the appropriate scope of appellate review resulting from this ruling.

\section{A short primer on the applicable law}

Under international trade law, a country does not have free rein to ban or restrict imports from another country simply because its trading partner has been afflicted with an agricultural disease. The SPS Agreement establishes detailed rules concerning when countries may restrict agricultural imports to protect human, animal, or plant life or health.

Because many agricultural diseases are monitored by international agencies, the law differentiates between scenarios when an international standard, guideline, or recommendation has been issued concerning agricultural goods affected by a given disease and when it has not. If a WTO member's measure is based on an international standard, guideline, or recommendation, then it is presumed legal, pursuant to Article 3.2. Article 3.3 clarifies that a country may deviate upward so long as it meets additional requirements set forth in that provision. ${ }^{3}$

Additionally, Article 5.7 restricts the use of restrictions based on the precautionary principle to instances 'where relevant scientific evidence is insufficient' such as when the impact of a new pathogen remains unknown. However, a WTO Member may only apply such a restriction on a provisional basis and must 'seek to obtain additional information necessary for a more objective assessment of risk' and review the measure accordingly 'within a reasonable period of time'.

In addition, Article 5.1 requires that any restrictive measure must be based on risk assessment, keeping in mind techniques developed by relevant international organizations. Article 2.2 further requires that the restriction be based on scientific principles and is not maintained without sufficient scientific evidence.

3 This includes providing scientific justification or demonstrating that the upward departure is the appropriate level in accordance with the relevant obligations set forth in Article 5 of the SPS Agreement. 
Article 6.1 requires that a WTO Member ensure that any restriction is adapted to the characteristics of the area from which the product originated and to which the product is destined. Such an area may be 'all of a country, part of a country, or all or parts of several countries'. Finally, Article 6.3 requires an exporting country claiming that part of its territory is disease-free to provide evidence and allow reasonable access to trading partners to demonstrate that this is and will remain the case.

WTO law on agriculture and food safety serves as a reminder of the trilemma confronting the global economy (Rodrik, 2011). So long as the nation-state remains the focal point for advancing globalization, deeper economic integration requires trading off some degree of direct democratic governance. Governments in WTO member-states do not possess a carte blanche to prohibit or otherwise restrict agricultural imports from disease-ridden trading partners. Decisions made by technocrats in international organizations affect and constrain the government's response.

\section{How India's response to bird flu gave rise to a trade dispute}

A government therefore finds itself in a precarious situation when an agricultural disease breaks out in a trading partner. On the one hand, it can choose to simply work through the international standard-setting organization to set the appropriate standards and guidelines and then implement the agreed-upon recommendation. As far as consistency with WTO law is concerned, this course of action is safest. However, it may prove costly domestically. Constituents may criticize the government for deferring to an international body rather than exercising its own sovereign authority.

Choosing alternatively to establish one's own policies for imports from the afflicted country carries its own risks. While WTO law allows for deviations, a government must follow a number of requirements. The India-Agricultural Products dispute offers a case study of how this latter approach can give rise to trade conflict.

\subsection{Avian influenza and India's import restrictions}

Avian influenza (AI) is an infectious viral disease that can spread quickly across birds with no apparent signs of illness. Once it hits, AI can devastate poultry stock. Incidences have been reported worldwide. AI is tracked by the World Organization for Animal Health (OIE), an international organization. The OIE establishes recommendations for different strains of AI, codified in the OIE Terrestrial Health Code. AI strains can be classified into two categories - high pathogenic (HPAI) or low pathogenic (LPAI) - with the former being much more deadly. Countries are required to report all occurrences of HPAI and of certain types of LPAI to the OIE. 
Among the countries that have reported AI is the United States, the world's second-largest poultry meat exporter, which last reported a case of HPAI in 2004. In the intervening decade, the United States has reported several instances of LPAI. India, too, has notified to the OIE of 95 HPAI outbreaks in the decade between 2003 and 2013. However, India has never notified an outbreak of LPAI.

On 19 July 2011, India's Department of Animal Husbandry, Dairying, and Fisheries (DAHD), pursuant to the powers conferred to it by the Livestock Act of 1898, issued S.O. 1663(E). This regulatory measure imposed an import ban on imports of live birds, poultry, eggs, feathers, and several other poultry-related products from all countries reporting HPAI and LPAI. Restrictions could be lifted once a country demonstrated that it was AI-free. On 7 October 2011, India provided notice of S.O. 1663(E) to the WTO's SPS Committee.

India justified its restrictions on the basis of worldwide AI outbreaks. However, the government also could have been motivated by the desire to protect its poultry industry from foreign competition. India is the third-largest producer of table eggs in the world, behind China and the United States; per-capita consumption of eggs grew by 33\% between 2002 and 2012 (Kotaiah, 2013). India is also the fourthlargest producer of broiler products in the world, after China, the US, and Brazil (ibid.).

Interestingly, the structure of chicken farming looks quite different in India. Only $16 \%$ of all Indian poultry is raised in intensive systems (i.e., large-scale, mechanized operations). By contrast, for developing countries as a whole, this percentage is 65\%, while it exceeds 90\% in China (Robinson, 2011: 57). Unlike elsewhere, Indian poultry farming involves mainly small and medium-sized farms where poultry farming is not the primary enterprise but done to supplement income and diet.

Therefore, a devastating AI outbreak affects the overall political economy differently in India. Whereas elsewhere it implicates primarily corporate interests, in India an outbreak afflicts harm on an enormous number of households. In a democratic country with over 250 million farmers and in which the majority of the workforce is dependent on agriculture-related activities to make a living, ${ }^{4}$ this can have enormous political consequences. Not surprisingly, the Indian government was keen to keep AI outbreaks at bay.

Did India's poultry farmers face a foreign threat, necessitating government protection? Not necessarily. At present, opportunities for imported poultry products are extremely limited. Indians overwhelmingly prefer to buy their chickens and eggs fresh. Over 93\% of boiler products in India are purchased live, whereas most imports are frozen (Kotaiah, 2013). Yet, consumption patterns will change

4 Salve (2014) notes that the 2011 Census reports 118.9 million cultivators, which amounts to nearly $25 \%$ of the total workforce. When agricultural laborers are included, that number rises to 263 million. 
as household incomes grow and urbanization increases, and some farmers may perceive a looming threat.

What the above discussion demonstrates is that it is not always easy to discern the underlying motivation of a government imposing import restrictions on agricultural products from disease-ridden trading partners. Genuine concerns over health, political considerations, and protectionism could all be part of the equation - the exact contribution of each of these factors is difficult to know with certainty.

\subsection{Why fuss over India's import restrictions?}

Importantly, India was not alone in enacting import bans on poultry and poultryrelated products from countries affected by AI. A number of other developing countries also enacted bans including Ecuador, the Philippines, and Saudi Arabia (Nedumpara et al., 2016: 215-216). However, it was India's measures that the US chose to challenge. Why target India?

In their insightful analysis of the Panel Report for this series, Bown and Hillman (2016) note several useful facts about the dispute. First, the US is the largest producer of poultry in the world. Major US poultry producers have been fairly effective in getting the government to respond to its interests, leading to seven antidumping investigations, and 12 WTO disputes involving poultry between 1995 and 2014. Second, though India is a country with a large population, it is not (yet) an important market for US poultry exports. In fact, in a typical year, Indian imports of poultry from the US are estimated to be a paltry $\$ 2$ million or so. Considering that the US global exports amount to roughly $\$ 5$ billion a year, the Indian economy absorbs approximately $0.04 \%$ of US poultry exports.

Classical trade policy models teach us that the trade policy interventions of small markets are inconsequential for exporters since they do not affect world prices. An import ban on poultry imposed by India should simply mean that US poultry exports that would have been sold in India should find their way to alternative markets without having any real effect on world prices and therefore US exporters.

Be that as it may, there are several reasons why the US poultry industry might care about an Indian ban on poultry justified on the basis of an outbreak of avian flu in certain parts of the US. First, given the pace of economic growth in India during recent decades, the US poultry industry might rationally expect the Indian market to become significantly more important over time. As Indian consumers get richer and start to consume more animal protein, demand for poultry in India is likely to increase significantly over time. This is particularly so because roughly $80 \%$ of India's population is Hindu and most practicing Hindus do not eat beef. Furthermore, approximately $13 \%$ of Indians are Muslims and Islam forbids the consumption of pork. Poultry products are consumed by both groups and are therefore of unique relevance to India as a source of animal protein.

Since initial market penetration can play an important role in long-run market control and brand recognition, if the US expects Indian consumption to take off 
in the future through habit formation (enhanced by low and declining real prices of poultry), then maintaining and growing share today is critical. Losing presence in the Indian market today could result in fairly large losses in the future.

Additionally, the US might be concerned that other countries will enact a ban similar to that of India. A successful challenge at the WTO guards against this possibility.

\subsection{The WTO challenge and Panel Report}

On 6 March 2012, the United States requested consultations, alleging that India's restrictions violated GATT Article XI and multiple provisions of the SPS Agreement. The US asserted that India's restrictions were not based on or in conformity with international standards as set forth in the OIE Terrestrial Code (SPS Articles 3.1 and 3.2). It further alleged that the measures were discriminatory (SPS Article 2.3), not based on a risk assessment (SPS Articles 5.1 and 5.2), arbitrary or unjustifiable distinctions (SPS Article 5.5), and more trade restrictive than necessary to achieve the proper level of protection (SPS Article 5.6). The US also contended that India failed to recognize that the US had a system of certifying certain regions as AI-free and therefore its ban on imports from the entire country was unjustified (SPS Articles 6.1 and 6.2). Finally, the US argued that India violated the WTO's notification and transparency requirements (SPS Article 7 and Annex $\mathrm{B}(2)$ and $\mathrm{B}(5)(\mathrm{a}),(\mathrm{b})$, and (d)).

On 14 October 2014, the Panel ruled overwhelmingly in favor of the United States. The US succeeded in all but two of its claims, for which the Panel exercised judicial economy. ${ }^{5}$ Because Bown and Hillman (2016) have already provided an excellent analysis on the Panel Report in this series, we refer readers interested in further details to their article.

\subsection{The appeal}

On 26 January 2015, India appealed all of the Panel's findings of violations of the SPS Agreement, except those concerning violations of the notification and timing requirements set forth in SPS Agreement Article 7 and Annex B. For several of its claims, India alleged that the Panel violated DSU Article 11 because it failed to make an objective assessment of the matter. In addition, with respect to the Panel's ruling that India failed to conform to international standards in violation of SPS Articles 3.1 and 3.2, India argued that the Panel also violated DSU Article 13 because it had improperly consulted relevant experts when making its ruling.

On 4 June 2015, the Appellate Body circulated its ruling. In all but one instance, the Appellate Body upheld the Panel's ruling. Only on the issue of whether India violated SPS Agreement Article 2.2 did the Appellate Body find that the Panel had erred in its approach. However, the Appellate Body was not able to complete the analysis. We will focus more on the implications of this specific ruling in Section 5 of this Article.

5 The Panel exercised judicial economy on the claims concerning SPS Article 5.5 and GATT Article XI. 
Although India had legitimate reasons to be concerned about AI exposure on account of the large population of farmers involved in poultry rearing, it nevertheless could not simply restrict imports of poultry products from AI-affected countries as the government saw fit. Part of the bargain of enjoying the benefits of the WTO involves agreeing to work through the international system to determine how best to regulate agricultural imports from disease-laden countries and regions.

\section{An economic analysis of India's import restriction}

Global pandemics know no borders. But this does not mean that the optimal policy response is simply to close off one's borders entirely to imports from disease-afflicted countries as India opted to do. Under what circumstances is such a ban justified from an economic welfare perspective? We address this question below in a simple economic model that is useful for illustrating the basic considerations at work.

\subsection{A simple economic model to analyze India's import restriction}

Suppose the imports of US poultry inflict a negative externality on the Indian economy that is not internalized by consumers. Let the damage caused by one unit of poultry imports be denoted by $\delta$. The parameter $\delta$ captures all of the external costs imposed on the Indian economy by each unit of poultry imported by the US. Let $p$ denote the local price of poultry in India. Let the domestic supply curve for poultry in India be given by

$$
q_{S}(p)=\frac{p}{2}
$$

and the domestic demand curve by

$$
q_{D}(p)=a-\frac{p}{2}
$$

Then, $m(p)=q_{D}(p)-q_{S}(p)$ measures India's imports of poultry and the Indian import demand curve for poultry is given by

$$
m(p)=a-\frac{p}{2}-\frac{p}{2}=a-p
$$

Assume that the US poultry industry is perfectly competitive and that India is a small buyer of poultry on world markets so that it faces a perfectly elastic export supply curve at the price $p_{W}$. Under free trade, Indian imports of US poultry equal

$$
m_{F}=a-p_{W}
$$

The welfare of the Indian economy as a function of the level of imports equal the sum of the surplus enjoyed by consumers and producers net of the damage caused by imports. The net effect of trade on local producers and consumers can be 
measured by the area underneath the import demand curve so that the welfare of the Indian economy under free trade can be written as

$$
W=\int_{p_{W}}^{a}\left(a-p_{W}\right) d p-\delta m_{F}
$$

The above welfare function simplifies to

$$
W=\frac{1}{2}\left(a-p_{W}\right)^{2}-\delta m_{F}
$$

which can be rewritten as

$$
W\left(m_{F} ; \delta\right)=\frac{1}{2}\left(m_{F}\right)^{2}-\delta m_{F}=m_{F}\left(\frac{m_{F}}{2}-\delta\right)
$$

Observe from this formula that sufficiently high damage caused by imports can make the net gains from trade enjoyed by the Indian economy negative. More specifically, we can see that given a positive level of imports, i.e. $m_{F}>0, W\left(m_{F} ; \delta\right)>0$ iff $m_{F}>2 \delta$ which is the same as $\delta<a-p_{W}$. In other words, if the external damage imposed on India by each unit of poultry imported from the US is sufficiently large, then international trade in poultry with the US makes India worse off relative to no trade. This implies that the Indian trade restrictions on imported poultry could potentially be justified. But this is not to say that a complete import ban on US poultry can always be rationalized on the basis of the above analysis.

This raises the following question: what is the optimal quantity of imports from the Indian perspective? We address this question next.

\subsection{The optimal import quota}

Suppose the Indian government were to institute an import quota denoted by $q$ that is less than the free trade level of imports, i.e., $q<m_{F}$. Since the quota creates local scarcity, the price in the Indian economy increases above the free trade price $p_{W}$. From the Indian import demand curve for poultry, the domestic price in India associated with the import quota $q$ is given by $p=a-q$.

Since $p$ will generally exceed the supply price of exporters $p_{W}$, those that have the right to import can derive some rent from it. Assume that this right to import is granted via licenses allocated to domestic agents via a competitive auction that allows the Indian government to collect the entire rent generated by the quota as license revenue. ${ }^{6}$ The revenue earned by those holding quota licenses is given by

$$
R=\left(p-p_{W}\right) q=\left(a-q-p_{W}\right) q
$$

6 Although the economic rationale behind such auctions is fairly sound, they are rarely used in practice. Depending upon how the government allocates the quota licenses, the total rent $R$ generated by the quota will generally be split between the government and license-holders. In the special case of a voluntary export 
Total welfare in India as a function of the quota can be written as

$$
W(q)=\frac{1}{2}(q)^{2}-\delta q+\left(a-q-p_{W}\right) q
$$

The optimal import quota $q$ maximizes total welfare $W(q)$. The first order condition for this maximization problem is given by

$$
\frac{d W(q)}{d q}=q-\delta+\left(a-q-p_{W}\right)+q(-1)
$$

The above first order condition can be solved for the optimal import quota $q$ * from India's perspective

$$
q^{*}=\left(a-p_{W}\right)-\delta
$$

which can be rewritten as

$$
q^{*}=m_{F}-\delta
$$

The above formula for the optimal import quota for a product that inflicts a damage of $\delta$ per unit on the importing economy is quite intuitive. When $\delta=0$, imports of poultry impose no external damage and the optimal import quota permits the free trade level of imports. Intuitively, if an economy cannot affect world prices - which in our case means that the foreign export supply price $p_{W}$ facing Indian consumers is unaffected by the import quota - then free trade is the optimal policy provided imports impose no external costs on the economy. For all $\delta>0$, however, it is optimal for India to reduce the level of its imports by an amount that is equal to the external damage imposed by each unit of the imported good. Note also that that $q^{*}=0$ only when $\delta>a-p_{W}$, i.e., only when the external damage inflicted by imports is sufficiently high that a complete ban on imports is optimal.

Of course, instead of using an import ban, India could have restricted imports via an import tariff. Does it matter which measure is used? To answer this question, we first derive India's optimal import tariff on US poultry.

\subsection{The optimal import tariff}

Let $t$ be the per-unit specific tariff imposed by India on imports of US poultry. The export supply price $p_{W}$ is unaffected by the Indian tariff since India is assumed to be a small importer of poultry in world markets. Therefore, the domestic price $p$ in India under the tariff is simply the sum of the world price and the tariff: i.e.,

restraint (which is not particularly relevant in the present dispute), the quota rent accrues to foreign exporters. 
$p=p_{W}+t$. Indian imports with this tariff-ridden price equal

$$
m(t)=a-p_{W}-t
$$

Total tariff revenue generated by the import tariff equals

$$
T R=t m(t)=t\left(a-p_{W}-t\right)
$$

The optimal tariff from India's perspective maximizes its total welfare $W(t)$ where

$$
W(t)=\frac{1}{2}(m(t))^{2}-\delta m(t)+t m(t)
$$

The first order condition for welfare maximization is

$$
\frac{d W(t)}{d t}=m(t)\left[1+\frac{d m(t)}{d t}\right]+[t-\delta] \frac{d m(t)}{d t}=0
$$

Using

$$
m(t)=a-p_{W}-t
$$

and

$$
\frac{d m(t)}{d t}=-1
$$

the above first order condition simplifies to

$$
\frac{d W(t)}{d t}=-t+\delta=0
$$

from which we obtain the optimal import tariff as

$$
t^{*}=\delta
$$

The optimal Indian import tariff $t^{*}$ is nothing but the Pigouvian tax that corrects for the negative externality imposed by US poultry on the Indian economy and it exactly equals the per-unit damage $\delta$ caused by imports. The level of imports under this tariff equals

$$
m\left(t^{*}\right)=a-p_{W}-t^{*}=a-p_{W}-\delta=m_{F}-\delta
$$

Observe that $m\left(t^{*}\right)=q^{*}$ i.e. the optimal import quota $q^{*}$ and the optimal import tariff $t^{*}$ lead to the same level of imports and are therefore equally trade restrictive and completely equivalent from a welfare perspective. ${ }^{7}$

7 An important hurdle in the implementation of the optimal trade policy (be it the tariff $t^{*}$ or the quota $\left.q^{*}\right)$ is that there might be considerable uncertainty regarding the value of the damage parameter $\delta$. Under 


\subsection{A Graphical illustration of the key economic tradeoffs}

The general idea underlying the above analysis of import restrictions on a product imposing a negative externality on the importing country can be illustrated by a simple graph. In Figure 1, the marginal private benefit of imports to the importing economy is denoted by MPB and it is in fact the import demand curve $m=a-p$. Due to the presence of the negative externality, the marginal social benefit of a unit of imports falls short of the MPB by the amount $\delta$, the vertical distance between the two downward sloping curves. Observe that these two lines are parallel to each other since the damage imposed by each unit of imports is assumed to be constant and equal to $\delta .{ }^{8}$

While the socially optimal level of imports from the Indian economy's perspective equals $q^{*}$, the equilibrium level of imports under free trade equals $m_{F}$, where $m_{F}>q^{*}$. As a result, the net welfare of the Indian economy under free trade equals $\mathrm{A}+\mathrm{B}-\mathrm{C}$, where area $\mathrm{A}$ measures the gain in consumer surplus net of the loss of local producers, area $\mathrm{B}$ measures the revenue raised by the optimal quota or tariff, and the area $\mathrm{C}$ captures the loss incurred by the Indian economy due to the overconsumption of imports.

For all units lying in the interval $\left[q^{*}, m_{F}\right]$, the MSB of imports is lower than the market price $p_{W}$ so that these imports serve to reduce the importing country's welfare. The optimal trade policy induces the socially optimal level of imports $q^{*}$ and this can be achieved via either an import quota set exactly equal to this amount or by imposing the Pigouvian import tariff $t^{*}=\delta$, which ensures that the $\mathrm{MPB}$ of imports ends up coinciding with their MSB and thereby inducing the socially optimal level of trade.

If the damage parameter $\delta$ is sufficiently large (i.e. $\delta>a-p_{W}$ ), the optimal trade measure lowers the MSB to such an extent that its vertical intercept ends up lying below the free trade price $p_{W}$. Only under such a situation is the optimal trade policy to prohibit imports altogether. This is because when $\delta>a-p_{W}$ the MSB of each unit of imports is lower than their price $p_{W}$.

\subsection{Further discussion}

While our analysis above sheds light on the incentives of an importing nation to restrict trade when imports inflict an externality on the local economy, it is worth discussing how its conclusions depend upon some of the underlying assumptions. In particular, the model assumes that imports impose a negative welfare

such a situation, in the presence of risk aversion on the part of local consumers, it could be optimal for India to impose fairly stringent restrictions on imported poultry. The economic analysis presented above assumes that the damage parameter $\delta$ is known with certainty and therefore eliminates any role for risk aversion, which can be significant in the presence of health risks.

8 If the damage imposed by imports were to increase with the level of imports, then the SMB curve would diverge away from the PMB curve with an increase in imports. 
Figure 1. Optimal trade policy under an externality

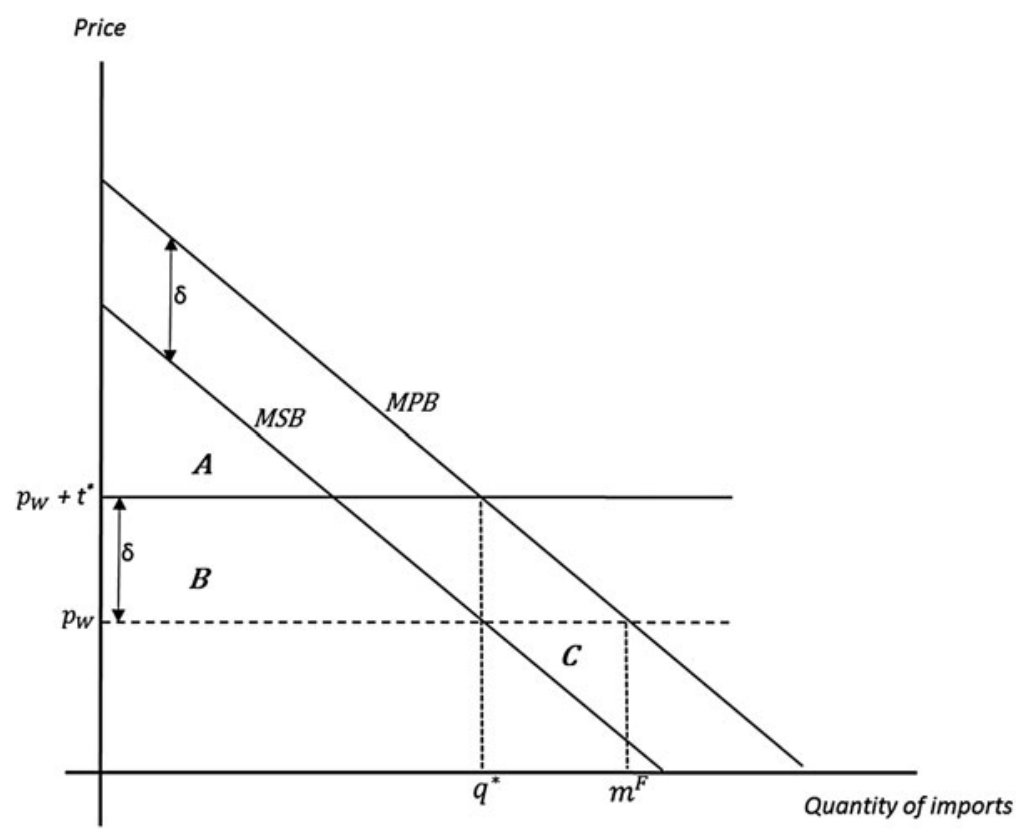

externality but is silent about the exact incidence of the externality. In the present dispute, the externality could be thought of as generating a health risk for the local population and this view is certainly consistent with our formulation above. Alternatively, one might think of imports having an adverse effect on local poultry suppliers in India due to the potential transmission of avian flu from imported to local poultry. Does it matter how one formulates this issue?

Second, our analysis above ignores the fact that restrictive trade policies were not the only available option for India. For example, India could also have subjected imports of poultry to port inspections designed at eliminating tainted birds and/ or other types of mitigation measures, all of which involve significant resource costs. In what follows, we further discuss each of these issues.

Suppose each unit of imports reduces the domestic supply of poultry by $\delta$ units, where $\delta<1 .^{9}$ The domestic supply curve for poultry can then be written as

$$
q_{S}\left(p, p_{W} ; \delta\right)=\frac{p}{2}-\delta m\left(p_{W}\right)
$$

9 Our analytical framework can be easily extended to allow the damage parameter to be uncertain. For expositional ease, we assume that it is known with certainty. 
Since, by definition, $m\left(p_{W} ; \delta\right)=q_{D}\left(p_{W}\right)-q_{S}\left(p_{W} ; \delta\right)$, we have

$$
m\left(p_{W}, \delta\right)=a-\frac{p_{W}}{2}-\frac{p_{W}}{2}+\delta m\left(p_{W} ; \delta\right)
$$

which gives ${ }^{10}$

$$
m\left(p_{W}, \delta\right)=\frac{a-p_{W}}{1-\delta}
$$

Following our earlier analysis, we can show that local welfare under free trade declines with $\delta$ so long as the adverse impact of imports on domestic poultry is not so large that local supply is completely eliminated - in which case changes in $\delta$ have no further impact on local welfare. Thus, even under this alternative approach, the larger the negative impact of imported poultry on domestic poultry, the smaller the gains from trade. It is straightforward to show that import restrictions (in form of a tariff or a quota) once again have the potential to raise domestic welfare. ${ }^{11}$

While we focus on a welfare-maximizing framework, Margolis et al. (2005) consider a small open economy model along the lines of Grossman and Helpman (1995) in which trade policy responds to contributions made by organized lobby groups to the government and imports generate a negative local externality via the introduction of an invasive species. Their key result is that the equilibrium tariff in such a model exceeds the standard politically optimal tariff that obtains in Grossman-Helpman model (in which imports do not generate a negative externality). Thus, the point that trade restrictions can be welfare improving in the presence of trade-induced negative externalities is robust to the incorporation of political economy forces.

Motivated by the potential transmission of foot-and-mouth disease (FMD) from imported to domestic cattle, Paarlberg and Lee (1998) develop a three-country model in which imports from only one of the two exporting countries have an adverse effect on the domestic supply of beef in the importing country. They show that the optimal tariff imposed on the imports of the foreign country that is the source of the externality exceeds the standard optimal tariff (which equals the inverse of the elasticity of the export supply curve of that country) due to the risk of disease transmission. Furthermore, they show that the optimal tariff imposed on the other exporter (where there is no FMD disease) is simply the standard optimal tariff, which in our formulation is zero since we assume India to be a

10 Note that we cannot allow for $\delta=1$ since the level of imports cannot be pinned down by the model when one unit of imports reduces local supply by exactly one unit. In other words, for $\delta=1$, the level of imports is indeterminate.

11 Actually, one can make a stronger claim: as Bown and Hillman (2016) observe, as per the targeting principle of Bhagwati and Ramaswami (1963) trade measures are the first-best means of addressing tradeinduced externalities. 
small importer of poultry that it is unable to extract any terms of trade gain via restrictive trade policies. The findings of Paarlberg and Lee (1998) show that the logic underlying our economic analysis extends to a setting where the importing country has market power. Furthermore, their results also lend support to the SPS agreement's requirement that any sanitary measures imposed on imports take account of differences in regional conditions across as well as within countries. $^{12}$

McAusland and Costello (2004) investigate how an importing country can use import tariffs in conjunction with port inspections to address the negative externality imposed on the local economy by an imported product. Their key result is that it is optimal for the importing country to use both instruments: the optimal import tariff is set at its Pigouvian level to take into account both the external damage imposed by those imports that are permitted as well as the cost of inspecting them. Intuitively, the possibility of costly inspections does not eliminate the need to reduce the level of imports in order to reduce the expected damage imposed on the local economy from infected poultry. ${ }^{13}$

In this context, it is also worth noting that an import ban imposed by a sizeable market could potentially help induce better regulation of poultry production in the exporting country (it could even be self-regulation by the exporting industry) where it is implicitly understood by both sides that a reduction in the probability of disease could lead to the ban being lifted. Under such an international bargain, the eventual outcome could Pareto dominate both autarky as well as a costly and imperfect inspection regime on the importing side.

What if the negative externality introduced is non-linear? An important realworld feature of disease-related negative externalities is that they can grow over time in a non-linear manner. For example, such externalities could be exponential, S-shaped, or concave. In order to keep our model relatively simple, we have abstracted from the possibility of such dynamic effects. While our approach is in line with the rest of the existing literature discussed above, it is worth noting that this is an important omission.

The work of Olson and Roy (2010) informs our understanding of optimal trade policy when the externalities induced by trade have inter-temporal consequences and the external costs imposed by imports evolve over time. They show that an efficient trade policy balances the welfare costs of any restrictive measure against the discounted stream of the future costs of control and the social damages that

12 Wilson and Anton (2006) build on Paarlberg and Lee (1998) by introducing mitigation strategies into their model. They show that provided the costs of mitigation strategies are not prohibitive, their use can generate net welfare gains and that the efficient sharing of such strategies between trading partners calls for taking account of their relative efficacy in mitigating tasks.

13 McAusland and Costello (2004) also consider a scenario where the importing country sources from multiple trade partners that are potentially heterogeneous in terms of underlying parameters (of which the extent of damage caused by imports is one). Like Paarlberg and Lee (1998), their main finding here is supportive of the idea that import measures should take into account variations in regional conditions. 
are avoided due to the trade measure. They also provide conditions under which it is optimal to impose a complete ban on imports versus when non-prohibitive trade policies are efficient.

In their model, the optimal level of a SPS trade restriction varies in a non-monotonic way over time. A complete ban is optimal when the existing stock of disease is such that further entry can generate a 'big' growth or spread of the disease; if the pre-existing prevalence of disease in the importing nation is either very small or very large, the marginal growth rate of the disease is not significant and so the import of tainted birds is not as consequential - but in the middle range, it can be explosive. With regard to avian flu and poultry, it is conceivable that the rate of spread can be very large even if the existing infestation is small (i.e. the growth function maybe concave as opposed to being S-shaped). If so, relatively harsh trade restrictions may be justified from a welfare perspective.

\section{Legal clarifications on key principles}

As the above economic analysis demonstrates, it is not always optimal for a government to ban imports of an agricultural product from a disease-inflicted region. Under certain circumstances, other less-restrictive measures may prove preferable.

While WTO law provides countries with the freedom to determine the appropriate level of protection (ALOP) in the wake of a disease outbreak, it places constraints on the design of the policy measure to be enacted to achieve the desired ALOP. Besides emphasizing the core principles of non-discrimination and transparency, WTO law stresses: (1) the importance of international standards, and (2) the importance of risk assessment and scientific evidence. On both points, the recent India-Agricultural Products ruling by the Appellate Body provided additional legal clarification.

\subsection{Interpretation of international standards relevant for the agricultural disease}

Rather than allowing each country to set its own response to a global pandemic, WTO law provides incentives for countries to work together through an international standard-setting body to determine the appropriate response to a pandemic. Article 3.1 of the SPS Agreement requires that '[WTO] Members shall base their sanitary and phytosanitary measures on international standards, guidelines or recommendations, where they exist, except as otherwise provided for in this Agreement'.

Why privilege international standards at the expense of local governance? Why not let each country set its own response unilaterally?

As discussed, agricultural diseases carried by a pest or pathogen generate negative externalities. For example, with AI, both the production of poultry and their movement across borders can increase the prevalence of the disease. Furthermore, the negative impact of AI may spillover beyond the poultry producer 
itself to affect products, wild populations, producers of poultry-related commercial products, and so forth. However, neither the exporter nor the importer may concern themselves with these additional costs. In such a situation, regulation by a third party is necessary to address the negative externality involved.

At the international level, this responsibility is borne by an international organization overseeing the disease. This body serves three important functions, akin to that of the domestic regulatory agency. First, it acts as an information aggregator and disseminator. The international organization allows national authorities to pool information on the disease and serves as a clearinghouse. Second, the international body offers a forum for national actors to work out an effective policy response. Without it, countries might worry that each might engage in 'beggarthy-neighbor' policies, leading to a harmful race-to-the-bottom. The international body provides a means for countries to agree upon a common response to be taken, including addressing the question of whether it is necessary to ban the product from the diseased region outright. Finally, the international body serves a coordination function to address free riding and inefficient resource allocation. It allows for better management of resources to fight the disease.

In this dispute, both the United States and India agreed that an international standard existed - Chapter 10.4 of the OIE Terrestrial Code. Specifically, Article 10.4.1.10 states:

A Member shall not impose immediate bans on the trade in poultry commodities in response to a notification, according to Article 1.1.3 of the Terrestrial Code of infection with HPNAI and LPNAI virus in birds other than poultry, including wild birds.

The question presented before the Panel was whether India's ban conformed to this international standard.

India and the United States disagreed over the meaning of Article 10.4.1.10. India interpreted the language narrowly as differentiating between two scenarios when the AI virus is introduced via poultry versus via other birds. The purpose of Article 10.4.1.10, India argued, is to clarify that a ban is impermissible in the latter scenario. According to India, Article 10.4.1.10, by logic, suggests that a ban is permissible when AI is introduced via poultry, as was the case here. ${ }^{14}$ Thus, India asserted its response was based on the relevant international standard. The US interpreted the Terrestrial Code's meaning very differently - as endorsing trade from AI-afflicted countries with recommendations for proper safety control measures. ${ }^{15}$

The dispute therefore raises the question of how are WTO jurists to determine the meaning of an international standard when its meaning is unclear. The approach taken can have a direct bearing on the dispute's outcome. 
In this case, the Panel turned to consult the OIE directly over the Code's meaning. In response, the OIE clarified that ' $\mathrm{t}$ ] he intention of Article 10.4.1.10 was to discourage Member countries from imposing bans on trade in poultry'. ${ }^{16}$ On the basis of the OIE consultation, the Panel sided with the United States in finding that India's restriction did not conform to the applicable international standard.

On appeal, India asked that the Appellate Body overturn the Panel's ruling because the Panel had improperly consulted the OIE as to the interpretation of the Code. DSU Article 13 specifically provides Panels with the authority to seek information from experts. Additionally, in the context of the SPS Agreement, Article 11.2 states:

In a dispute under [the SPS] Agreement involving scientific or technical issues, a panel should seek advice from experts chosen by the panel in consultation with the parties to the dispute. To this end, the panel may, when it deems appropriate, establish an advisory technical experts group or consult the relevant international organizations, at the request of either party to the dispute or on its own initiative.

India argued that a Panel is only to consult on scientific or technical issues. India asked that the Appellate Body find that the Panel had overstepped its authority in seeking input from the OIE on the actual interpretation of the OIE Terrestrial Code. ${ }^{17}$

As Nedumpara et al. (2016: 221) highlight, India's approach suggests that the matter of interpreting the text of the international standard falls to the Panel itself. Because the text is not explicit on this question, under the proposed approach, the Panel would rely upon the customary rules of interpretation as set for in Articles 31-33 of the Vienna Convention on the Law of Treaties (VCLT). In other words, the meaning of Article 10.4.1.10 of the OIE Terrestrial Convention would be a question of law for WTO adjudicators to decide.

The approach suggested by the United States, by contrast, would render this to a question of fact. As such, the US argued, it would be entirely appropriate for a Panel to consult with the OIE over the meaning of Article 10.4.1.10. After all, who better to opine on the factual meaning of an international standard than the body that issued it?

The Appellate Body has long held that WTO law does not exist in 'clinical isolation' from public international law. As the Appellate Body again highlighted in this case, 'relevant customary rules of interpretation of public international law' can be relevant to the interpretation of WTO law. ${ }^{18}$ But these statements do not resolve the question over the nature of the relationship between WTO law and other bodies of public international law. In recent years, a sharp division has emerged over this question.

One point of view holds that WTO law is distinct. WTO covered agreements may reference other bodies of international law, but the job of a WTO jurist is 
simply to interpret the WTO covered agreements on its own terms and context. Another point of view argues that different bodies of law operate through a form of systemic integration. In certain circumstances, it may be necessary to look outside the four corners of WTO law itself and consider its context within the broader framework of international law when interpreting a treaty provision (McLachlan, 2005). Therefore, it would be entirely appropriate for WTO jurists to consider these other bodies of law, and vice versa; the system operates through a discursive dialogue. Needless to say, the two camps differ on their view of the proper role of a WTO Panel.

The approach suggested by India veers toward this latter camp. India suggested that a Panel's duty to interpret a WTO treaty provision does not stop at the boundaries of the agreements covered by the WTO. Instead, if the WTO treaty provision makes reference to an international standard promulgated by another body besides the WTO, then the duty of the WTO adjudicator is to opine on the meaning of that standard as well. By delegating this duty to outside experts instead of taking it on themselves, the Panel failed to fulfill what is required of it by the Dispute Settlement Understanding.

By siding with the US, the Appellate Body appears to be rejecting the strong version of the systemic integration narrative. At least with respect to international standards set by a non-judicial body that is relevant to the SPS Agreement, where there is textual ambiguity or uncertainty, the Appellate Body held that it is more than appropriate for a WTO Panel to consult the body that drafted and administers the standard to opine on its meaning. Because the OIE Terrestrial Code itself is not part of the WTO covered agreements, the Appellate Body suggested that the Panel was not obligated to opine on the Code's meaning by itself. Instead, it was perfectly fine for the Panel to ask the OIE, the body that administers the Code, for its interpretation instead.

Note that in so ruling, the Appellate Body is helping to prevent fragmentation of international law. Had it stated that the Panel could not consult the OIE on interpreting the Terrestrial Code, the Panel very well might have reached a different conclusion about its meaning than that of the OIE. By allowing the Panel to do so, it helps to ensure that the Code's meaning remains consistent across different bodies of international law, in line with the OIE's own interpretation.

Because international standards, recommendations, and guidelines play such an important role in trade disputes concerning agricultural diseases, the Appellate Body ruling provides important clarification over how such standards are to be interpreted. Panels can refer interpretative questions to international standardsetting organizations, just as national courts might consult regulatory agencies directly when needing to interpret a regulation. Again, this case highlights the extraordinary importance of the international standard-setting body, whose role is not simply limited to issuing standards, guidelines, and recommendations, but also weighing in on their interpretative meaning. 


\subsection{The relationship between the risk assessment and scientific evidence requirements}

Despite the deference given to international standards, WTO law does not demand conformity. Article 3.3 of the SPS Agreement clarifies that countries retain sovereign authority to establish its ALOP. However, WTO law demands that countries wishing to set a higher level of protection meet certain requirements. Among these are the requirements of Articles 5.1 and 5.2 to perform a risk assessment and Article 2.2 to base its measure on scientific principles and evidence.

In India-Agricultural Products, the Appellate Body was called upon to clarify the relationship between these provisions. At issue were two questions: First, can the risk assessment requirement of Article 5.1 be circumvented simply with recourse to 'scientific evidence' pursuant to Article 2.2? Second, if not, then does failure to conduct an adequate risk assessment automatically lead to a violation of Article 2.2?

Given the resource constraints faced by many developing countries, the answers to these questions have a direct bearing on what they must do in the wake of a global agricultural pandemic. By its own admission, India did not conduct a risk assessment in line with Articles 5.1 and 5.2. Yet, India had assembled some scientific evidence concerning AI that had supposedly served as the basis for its import ban. India argued that a risk assessment is not obligatory, but simply a method to fulfill its legal obligations. An alternative, India suggested, is to base the SPS measure on Article 2.2, which India had fulfilled.

On the first question, the Appellate Body clarified that these were not distinct choices. It held that 'SPS measures adopted by Members must comply with all of the requirements of Articles 2.2, 5.1, and 5.2 ${ }^{19}$ Article 2.2 does not serve as a means to circumvent the risk assessment requirement of Articles 5.1 and 5.2.

On the second question, the Appellate Body clarified that a failure to perform a risk assessment does not automatically lead to a violation of the 'scientific evidence' requirement of Article 2.2. Instead, the enacting government must be given an opportunity to present arguments and evidence to rebut such a presumption. ${ }^{20}$ Because the Panel failed to consider such arguments and evidence, the Appellate Body reversed the Panel's findings that India's measures, with respect to fresh poultry meat and eggs, were inconsistent with Article 2.2. However, the Appellate Body found that it lacked sufficient information to complete the analysis on whether the evidence submitted by India on fresh poultry meat and eggs would suffice to meet the requirement of Article 2.2.21

Therefore, the Appellate Body's ruling leaves unanswered the question of what information, absent a risk assessment, would suffice to meet the requirement of 
Article 2.2. The Appellate Body simply made clear that 'even though the presumption of inconsistency under Article 2.2 flowing from a violation of Articles 5.1 and 5.2 is rebuttable, establishing that there exists a rational or objective relationship between the SPS measure and scientific evidence for purposes of Article 2.2 would, in most cases, be difficult without a Member demonstrating that such a measure is based on an assessment of the risks, as appropriate to the circumstances'. ${ }^{22}$

What evidence might suffice? Returning to our economic model, we suggest that such evidence would have to clarify our understanding of the harm associated with the imports, as denoted by the parameter $\delta$ in the model. After all, it is the size of $\delta$ that determines whether the import restriction is justifiable or excessive. One could envision a scenario in which a government, without undertaking a full risk assessment, presents evidence concerning the expected harm associated with each unit of an import from a disease-afflicted region to justify its import restriction.

More importantly, we posit that this unanswered legal question is not a significant one. Why not? So long as the Panel finds the respondent to be in violation of Articles 5.1 and 5.2, even if the Panel further finds that scientific evidence submitted by the respondent meets the requirements of Article 2.2, the Party nevertheless will need to perform an adequate risk assessment in line with Articles 5.1 and 5.2 in order to bring its SPS measure into compliance. Thus, regardless of whether the evidence submitted is sufficient to rebut the presumption or not, the need for conducting a risk assessment remains paramount.

\section{Controversy over the scope of appellate review}

Finally, we draw attention to a controversy related to the Appellate Body's handling on one other legal element of this dispute. India - Agricultural Products represented the first time that the Appellate Body has opined on the meaning of Article 6 of the SPS Agreement concerning 'adaptation to regional conditions'. The Panel found India to have violated Articles 6.1 and 6.2 because its import ban applied across-the-board to all US exports and did not recognize the concepts of diseasefree and low-disease-prevalence areas. ${ }^{23}$ India acknowledged that it had not done so, but argued that it could not do so until the US fulfilled its obligation under Article 6.3, requiring the exporting country to provide objective evidence demonstrating that areas are, and likely to remain, disease-free or low-incidence. ${ }^{24}$ The Panel rejected India's argument; it held that the Article 6.1 and 6.2 are independent obligations and not conditional upon an invocation of Article 6.3. ${ }^{25} \mathrm{On}$ appeal, India asked the Appellate Body to reverse the Panel's finding of violation of Articles 6.1 and 6.2, arguing that the Panel erred in its interpretation of the

22 Ibid., para. 5.32

23 Panel Report, India-Agricultural Products, paras. 7.713-7.714.

24 Ibid., para. 7.633.

25 Ibid., para. 7.680 . 
relationship between Articles 6.1 and 6.3 and in its application of Article 6.2.26 The Appellate Body rejected India's arguments and upheld the Panel ruling. ${ }^{27}$

Having prevailed, one would not expect the Appellate Body's ruling to draw the ire of the United States. However, in its ruling, the Appellate Body chose to opine on several other elements of the Panel's analysis of Article 6, which India had not raised in its appeal. In particular, the Appellate Body 'consider[ed] it important to emphasize that what constitutes an appropriate order of analysis and approach by a Panel examining a claim under Article 6 may, at least in part, be a function of the nature of the claim and circumstances of that case'. ${ }^{28}$ The Appellate Body explained that it was 'not persuaded that all of the statements made by the Panel would have the same resonance in every case', suggesting that the proper inquiry into Article 6 depends on the particular context surrounding the dispute. ${ }^{29}$ The Appellate Body then proceeded to raise questions and 'concerns' over particular Panel statements. ${ }^{30}$

For the United States, this obiter dictum represented unnecessary and improper judicial activism by the Appellate Body. Neither the US nor India had challenged the particular Panel's statements and actions on appeal; thus, it was improper for the Appellate Body to opine on legal issues that had not been placed before it. In the Dispute Settlement Body meeting adopting the ruling, the United States emphasized that 'particularly at a time when workload issues were increasingly affecting the time-table for the resolution of disputes, a focus on those issues that had been appealed, and on questions that needed to be addressed in resolving the arguments raised on appeal, would facilitate the efficient functioning of the dispute settlement process'. 31

At the time, the US protest did not register much attention. However, nearly a year later, in May 2016, the United States further underscored its displeasure by withholding its support for the reappointment of Appellate Body Member Seung Wha Chang. In explaining its action, the United States noted the actions of four Appellate Body divisions on which Professor Chang had served, of which IndiaAgricultural Products was one, to which it objected. ${ }^{32}$ In discussing this dispute, the US again condemned the inappropriateness of the Appellate Body 'engag[ing] in a lengthy abstract discussion of a provision of the SPS Agreement without

26 Appellate Body Report, India-Agricultural Products, para. 5.112.

27 Ibid., paras. 5.186-5.187.

28 Ibid., para. 5.142 .

29 Ibid., para. 5.143.

30 Ibid., paras. 5.143-5.144.

31 WTO Dispute Settlement Body, Minutes of the Meeting Held in the Centre William Rappard on 19 June 2015, WT/DSB/M/364, para. 7.5.

32 The other three disputes mentioned are Argentina - Measures Relating to Trade in Goods and Services (DS453), United States - Countervailing Duty Measures on Certain Products from China (DS437), and United States - Countervailing Duty Measures on Certain Products from China (DS449). The concerns raised in each differ from that of India-Agricultural Products. 
ever tying that discussion to an issue on appeal and ... express[ing] "concerns" in that discussion on findings of the Panel that were not raised by either party in the appeal'. ${ }^{33}$ The US emphasized that '[i]t is not the role of the Appellate Body to engage in abstract discussions or to divert an appeal away from the issues before it in order to employ resources on matters that are not presented in, and will not help resolve, a dispute'. ${ }^{34}$

In blocking Professor Chang's reappointment, the United States has been roundly criticized as threatening the Appellate Body's judicial independence. ${ }^{35}$ Nevertheless, this dispute does raise valid questions over what is the proper scope of review by the Appellate Body. Article 17.2 of the Dispute Settlement Understanding (DSU) simply states, 'The Appellate Body shall address each of the issues raised ... during the appellate proceeding' (emphasis added). Article 3.7 also reminds us that the 'aim of the dispute settlement mechanism is to secure a positive solution to a dispute'. Nowhere in the DSU is the Appellate Body accorded the power to opine on elements of a Panel ruling with which it disagrees but which the parties have not raised. The function of the Appellate Body is not to act as a constitutional court in clarifying the law but simply to assist with resolving the dispute at hand. To the extent that the Appellate Body disagrees with elements of a Panel ruling not raised on appeal, it must wait for a future dispute raising this point to clarify - just as it would if the entire Panel ruling, and not only select parts, were not appealed.

It is unfortunate that it required as drastic a move as blocking Professor Chang's reappointment to underscore this point. To prevent further recurrences, future Appellate Body divisions ought to bear in mind the constraints placed on the scope of appellate review set forth in the DSU.

\section{Conclusion}

While disease outbreaks may well serve as a reason to curb trade in agricultural goods, WTO law places limits on this practice, out of fear that the response may be disproportionate and serve as an excuse for protectionism. The Appellate Body ruling in India-Agricultural Products reaffirms the applicability of two central tenets of the law: the importance of taking into account international standards when evaluating the legality of any restrictions and the importance of risk assessments. An underlying economic rationale underscores both tenets, related to the failure to internalize the negative externality associated with the disease and the need for information and coordination.

33 Statement of the United States at the Meeting of the WTO Dispute Settlement Body, Geneva, 23 May 2016, at 4.

34 Ibid.

35 'US Slammed at DSB For Blocking Korean Appellate Body Reappointment,' Inside US Trade, 34 (21), 27 May 2016. 
On both issues, the Appellate Body's ruling added to the existing jurisprudence on these issues. But beyond the jurisprudential questions, the Appellate Body ruling is also historic in that it is the first ruling to challenge the SPS measure of a developing nation. While India-Agricultural Products is the first; more challenges are in process, including one over Russia's import restrictions on pigs. The political economy is likely to be different in the context of a developing country where an agricultural disease has the potential to ravage a large number of households dependent on agriculture for their household income. But even so, the Appellate Body makes clear that the underlying legal principles remain the same. No matter the context, an outright ban is not generally warranted. Instead, it must be justified in light of the international response and the risks at hand.

\section{References}

Bhagwati, J. and V. K. Ramaswami (1963), 'Domestic Distortions, Tariffs, and the Theory of Optimum Subsidy', Journal of Political Economy, 71(1): 44-50.

Bown, C. and J. A. Hillman (2016), 'Bird Flu, the OIE, and National Regulation: The WTO's India Agricultural Products Dispute', World Trade Review, 15(2): 235-257.

Grossman, G. and E. Helpman (1995), 'Protection for Sale', American Economic Review, 84(4): 833-850.

Margolis, M., J. F. Shogren, and C. Fischer (2005), 'How Trade Politics Affect Invasive Species Control', Ecological Economics, 52(3): 305-313.

McAusland, C. and C. Costello (2004), 'Avoiding Invasives: Trade Related Policies for Controlling Unintentional Exotic Species Introductions', Journal of Environmental Economics and Management, 48(2): 954-977.

McLachlan, C. (2005), 'The Principle of Systemic Integration and Article 31(3)(C) of the Vienna Convention', International Comparative Law Quarterly, 53: 279-320.

Nedumpara, J., A. Chandra, and G. Deepak (2016), 'India - Agricultural Products: Defending India's First SPS Dispute', in A. Das and J. Nedumpara (eds.), WTO Dispute Settlement at Twenty: Insiders' Reflections on India's Participation, New Delhi: Centre for WTO Studies \& Springer.

Olson, L. J. and S. Roy (2010), 'Dynamic Sanitary and Phytosanitary Trade Policy', Journal of Environmental Economics and Management, 60: 21-30.

Paarlberg, P. L. and J. G. Lee (1998), 'Import Restrictions in the Presence of a Health Risk: An Illustration Using FMD', American Journal of Agricultural Economics, 80(1): 175-183.

Robinson, T. et al. (2011), Global Livestock Production Systems, Rome: Food and Agricultural Organization of the United Nations and International Livestock Research Institute.

Rodrik, D. (2011), The Globalization Paradox, New York, W. W. Norton.

Salve, P. (2014) 'How Many Farmers Does India Really Have', Hindustan Times, 11 August 2014.

Wilson, N. L. W. and J. Anton (2006), 'Combining Risk Assessment and Economics in Managing a Sanitary-Phytosanitary Risk', American Journal of Agricultural Economics, 88(1): 194-202.

World Trade Organization (2015), International Trade Statistics 2015. 